\title{
Inhibitory Actions of Procaterol, a Beta-2 Stimulant, on Substance P-Induced Cough in Normal Subjects during Upper Respiratory Tract Infection
}

\author{
Uichiro Katsumata, Kiyohisa Sekizawa, Hiroshi \\ Inoue, Hidetada Sasaki and Tamotsu Takishima
}

The First Department of Internal Medicine, Tohoku University School of Medicine, Sendai 980

\begin{abstract}
Katsumata, U., Senizawa, K., Inoue, H., Sasaki, H. and Takishima, T. Inhibitory Actions of Procaterol, a Beta-2 Stimulant, on Substance P-Induced Cough in Normal Subjects during Upper Respiratory Tract Infection. Tohoku J. Exp. Med., 1989, 158 (1), 105-106 — We studied substance P (SP)-induced cough in normal subjects without and with colds, and the effects of orally administered procaterol on SP-induced cough in normal subjects with colds. SP aerosols caused cough at a concentration of approximately $10^{-15} \mathrm{M}$ in subjects with colds whereas it did not cause cough at a concentration of up to $10^{-5} \mathrm{M}$ in subjects without colds. Procaterol $(50 \mu \mathrm{g})$ completely inhibited SP-induced cough in normal subjects with colds. These results suggest that cough response to SP remarkably increases during colds and that beta-2 stimulant may be a useful tool for treatment of cough during colds in normal subjects — cough ; substance $\mathrm{P}$; beta-2 receptor
\end{abstract}

A recent study in awake guinea pigs (Kohrogi et al. 1988) suggests that SP is a potent stimulant of cough responses. The actions of SP are modified by neutral endopeptidase (NEP) in the airway (Sekizawa et al. 1987) and NEP is reported to decrese after viral infection (Borson et al. in press). Therefore, we studied the effects of inhaled SP on cough responses and the effects of procaterol on SP-induced cough in normal subjects without and with colds.

The cough response and analyzed by determining cough threshold. Cough threshold was the concentration at which the subject coughed at least 5 times. Subjects inhaled saline aerosol, then concentrations of solution from $10^{-17} \mathrm{M}$, incremented 100 times. We measured forced expiratory volume at $1 \mathrm{sec}\left(\mathrm{FEV}_{1}\right)$ before and after experiments.

Experiment 1. We studied 5 normal subjects who had uncomplicated upper respiratory tract infections (colds) and 5 normal subjects without colds. SP and histamine solutions were administered in random order, double blind fashion, each on a separate day at the same time of day.

Experiment 2. We studied 3 normal subjects during the course of their colds. Procaterol $(50 \mu \mathrm{g})$ was orally administered $2 \mathrm{hr}$ before the experiment. Experiments with and without procaterol were performed in random order, each on a separate day at the same time of day. None of the subjects in the present study had a personal or family history of

Received April 27, 1989; revision accepted for publication May 23, 1989.

Reprint requests: T. Takishima, M.D., the First Department of Internal Medicine, Tohoku University School of Medicine, 1-1 Seiryo-machi, Sendai 980, Japan. 
TABLE 1. Effects of procaterol and substance $P$ on pulmonary function and cough thereshold

\begin{tabular}{ccccccc}
\hline \multirow{2}{*}{$\begin{array}{c}\text { Subject } \\
\text { No. }\end{array}$} & Sex & \multirow{2}{*}{$\begin{array}{c}\text { Age } \\
\text { (years) }\end{array}$} & \multicolumn{2}{c}{$\begin{array}{c}\mathrm{FEV}_{1} \\
(\mathrm{~L})\end{array}$} & \multicolumn{2}{c}{$\begin{array}{c}\text { Cough threshold } \\
(-\log \mathrm{M})\end{array}$} \\
\cline { 4 - 7 } & & & $\mathrm{P}(-)$ & $\mathrm{P}(+)$ & $\mathrm{p}(-)$ & $\mathrm{P}(+)$ \\
\hline 1 & $\mathrm{M}$ & 30 & $3.96(4.01)$ & $4.14(4.06)$ & 13 & $<5$ \\
2 & $\mathrm{M}$ & 33 & $3.61(3.60)$ & $3.91(3.96)$ & 13 & $<5$ \\
3 & $\mathrm{~F}$ & 23 & $2.83(2.74)$ & $3.18(3.04)$ & 11 & $<5$ \\
\hline Mean & & 29 & $3.47(3.45)^{*}$ & $3.76(3.69)$ & $12.3^{* *}$ & $<5$ \\
\pm S.E. & \pm 5 & $\pm 0.33( \pm 0.37)$ & $\pm 0.29( \pm 0.32)$ & \pm 0.7 & \\
\hline
\end{tabular}

Values are means \pm S.E. except for the average age (mean \pm S.D).

$\mathrm{FEV}_{1}$, forced expiratory volume at $1 \mathrm{sec} ; \mathrm{P}(-), \mathrm{P}(+)$, without and with procaterol. Comparison of cough threshold between with and without procaterol was done by putting the number of 5 as cough threshold with procaterol. ${ }^{*} p<0.05,{ }^{* *} p<0.01$ against values with procaterol. Values in parenthese are those obtained after inhalation of substance $\mathrm{P}$.

asthma, and none had suffered from any cardiopulmonary diseases.

Saline aerosols did not cause cough in all subjects in all conditions. SP caused cough at a concentration of $14.6 \pm 0.7(-\log \mathrm{M}$; mean \pm s.E.) in subjects with colds whereas it did not cause cough at concentrations of up to $10^{-5} \mathrm{M}$ in subjects without colds. Histamine did not cause cough to $10^{-5} \mathrm{M}$ concentration in either subjects with or without colds. Orally administered procaterol $(50 \mu \mathrm{g})$ surprisingly showed complete inhibition of SP-induced cough in subjects with colds. Procaterol significantly increased $\mathrm{FEV}_{1}$ (Table 1), indicating that it dilated the airways. However, SP did not alter $\mathrm{FEV}_{1}$ with and without procaterol (Table 1), suggesting that procaterol did not inhibit cough responses to SP by relief of SP-induced bronchoconstriction. Although oral beta stimulants have been found to be effective in "allergic cough" associated with an increase in $\mathrm{FEV}_{1}$, there is no general agreement about the effect of beta stimulants on induced cough. Procaterol may inhibit SP-induced cough by an action other than the dilating effect on airway smooth muscle. Aerosols of SP fragment ${ }_{1-9}$, a major metabolite of NEP, caused cough only at concentrations greater than $10^{-7} \mathrm{M}$ in another 3 subjects with colds. Inhibitors of NEP potentiated cough responses to SP in awake guinea pigs (Kohrogi et al. 1988), and acute viral infection are known to cause epithelial damage in humans, which would decrease NEP in the airways (Borson et al. in press). Therefore, decrease in NEP in the airway may occur during colds, thereby increasing the cough response to SP in subjects with colds.

The present study suggests that SP is a potent cough stimulant during colds and oral administration of beta-2 stimulant may be a new and useful tool for treating cough during colds in normal subjects.

\section{References}

1) Borson, D.B., Brokaw, J.J., Sekizawa, K., McDonald, D.M. \& Nadel, J.A. Neutral endopeptidase and neurogenic inflammation in rats with respiratory infection. $J$. Appl. Physiol., (in press)

2) Kohrogi, H., Graf, P.D., Sekizawa, K. \& Nadel, J.A. (1988) Neutral endopeptidase inhibitors potentiate substance $\mathrm{P}$ - and capsaicin-induced cough in awake guinea pig. J. Clin. Invest., 82, 2063-2068.

3) Sekizawa, K., Tamaoki, J., Graf, P.D., Basbaum, C.B., Borson, D.B. \& Nadel, J.A. (1987) Enkephalinase inhibitor potentiates mammalian tachykinin-induced contraction in ferret trachea. J. Pharmacol. Exp. Ther., 243, 1211-1217. 